\title{
Bioremediation of petroleum hydrocarbons from crude oil- contaminated soil with the earthworm: Hyperiodrilus africanus
}

\author{
O. A. Ekperusi ${ }^{1}$ - F. I. Aigbodion ${ }^{1}$
}

Received: 28 November 2014 / Accepted: 23 March 2015/Published online: 9 April 2015

(C) The Author(s) 2015. This article is published with open access at Springerlink.com

\begin{abstract}
A study on the bioremediation potentials of the earthworm Hyperiodrilus africanus (Beddard) in soil contaminated with crude oil was investigated. Dried and sieved soils were contaminated with $5 \mathrm{ml}$ each of crude oil with replicates and inoculated with earthworms and monitored daily for 12 weeks. Physicochemical parameters such as $\mathrm{pH}$, total organic carbon, sulfate, nitrate, phosphate, sodium, potassium, calcium and magnesium were determined using standard procedures. Total petroleum hydrocarbon (TPH) was determined using atomic absorption spectrophotometer (AAS), while BTEX constituents and earthworms tissues were analyzed using Gas Chromatography with Flame Ionization Detector (GC-FID). The results showed that the earthworm significantly enhanced the physicochemical parameters of the contaminated soil resulting in a decrease of the total organic carbon $(56.64 \%)$, sulfate $(57.66 \%)$, nitrate $(57.69 \%)$, phosphate $(57.73 \%)$, sodium $(57.69 \%)$, potassium $(57.68 \%)$, calcium $(57.69 \%)$ and magnesium $(57.68 \%)$ except $\mathrm{pH}(3.90 \%)$ that slightly increased. There was a significant decrease in the TPH $(84.99 \%)$, benzene $(91.65 \%)$, toluene $(100.00 \%)$, ethylbenzene $(100.00 \%)$ and xylene $(100.00 \%)$. Analyses of the tissues of the earthworm at the end of the experiment showed that the earthworms bioaccumulated/biodegraded 57.35/27.64 \% TPH, 38.91/52.73\% benzene, 27.76/72.24\% toluene, $42.16 / 57.85 \%$ ethylbenzene and $09.62 / 90.38 \%$ xylene. The results showed that the earthworms $H$. africanus could be
\end{abstract}

O. A. Ekperusi

ekperusiab@gmail.com

1 Environmental Quality Management Programme, Department of Animal and Environmental Biology, Faculty of Life Sciences, University of Benin, Benin City, Nigeria used to bioremediate moderately polluted soil with crude oil contamination in the Niger Delta region of Nigeria.

Keywords Vermiremediation - Crude oil - Earthworms · Hyperiodrilus africanus · Nigeria

\section{Introduction}

The petroleum industry in Nigeria is the largest in the West African region and the second largest in Africa after Algeria. Nigeria has a total of 159 oil fields and 1481 wells in operation (NDES 1997). According to the Nigerian National Petroleum Corporation (NNPC) 2013 Annual Statistical Bulletin on the oil and gas industry, a total crude oil and condensate production for the year was $852,776,653$ barrels, giving a daily average of 2.27 million barrels per day (mb/day). These figures put Nigeria in the fifteenth position in relation to the global oil producing nation and the sixth largest exporter of crude oil worldwide (NNPC 2013).

All activities surrounding the oil sector such as exploration, drilling, transportation, refining and consumption of oil and its associated products result in the spilling of oil and refine products into the environment. In 2013 alone, the NNPC reported a total of 2256 line breaks on NNPC pipelines resulting in a loss of 181.67 million tonnes (mt) of petroleum products worth about N21.48 billion, with 34 cases of fire incidents during the year under review (NNPC 2013).

Crude oil contains a wide range of compounds which are largely toxic to humans and the environment. Some authors have suggested that soil remediation standards should be based on the BTEX components in crude oil and oil products (fuels)-impacted soils (Salanitro et al. 1997). 
Although BTEX are known to vapourize in contaminated sites, they can remain locked in soil for months and even years as reported by the United Nations Environment Program assessment in Ogoniland (UNEP 2011), hence they need special attention in crude oil-contaminated soil. Each of these compounds or their combination poses a serious concern to human health, living organisms and the environment. Benzene is a notorious cause of bone marrow failure. Substantial quantities of epidemiologic, clinical, and laboratory data link benzene to aplastic anemia, acute leukemia, and bone marrow abnormalities (Kasper et al. 2004) and myelodysplastic syndrome (Smith 2010). Human exposure to benzene is a global health problem. Benzene targets liver, kidney, lung, heart and the brain and can cause DNA strand breaks, chromosomal damage, etc. Benzene causes cancer in animals including humans and has been shown to cause cancer in both sexes of multiple species of laboratory animals exposed via various routes (Huff 2007; Rana and Verma 2005). The United States Environmental Protection Agency (EPA) has classified benzene as a known human carcinogen for all routes of exposure (EPA 2012). The central nervous system (CNS) is the primary target organ for toluene toxicity in both humans and animals for acute and chronic exposures (EPA 2012). Animal studies have reported effects on the blood, liver, and kidneys from chronic inhalation exposure to ethylbenzene. Exposure to ethylbenzene by inhalation resulted in an increased incidence of kidney and testicular tumors in rats, and lung and liver tumors in mice (EPA 2000). Ethylbenzene is classified as a possible carcinogen by the International Agency for Research on Cancer (IARC 2012).

Beside, the use of chemicals and mechanical methods for cleaning oil in the environment, one of the most promising bioremediation technologies is the use of earthworms in a processed specifically known as vermiremediation.

The idea to use earthworms in vermicomposting of gardens and crop enhancement has been known for centuries, but its application in bioremediation according to available records was incidentally discovered after the Seveso chemical plant explosion in 1976 in Italy, when a vast area was contaminated with extremely toxic chemical such as 2, 3, 7, 8-tetrachlorodibenzo-p-dioxin (TCDD). Several fauna perished except for some species of the earthworms that survived. Earthworms which ingested TCDD-contaminated soils were shown to bioaccumulate dioxin in their tissues and concentrated it on an average of 14.5-fold (Satchell 1983).

Several researches have established the potentials of earthworms to bioremediate crude oil and other petrochemicals from laboratory and field trials polluted soil. Ma et al. (1995) studied the influence of earthworm species
Lumbricus rubellus on the disappearance of spiked PAHs, phenanthrene and fluoranthene $(100 \mu \mathrm{g} / \mathrm{kg}$ of soil), and found that the losses of both PAHs occurred at a faster rate in soils with earthworms than the soil without worms. After 56 days ( 8 weeks), $86 \%$ of the phenanthrene was removed.

Other studies have also shown that oil-polluted soils can be efficiently bioremediated, leading to a reduction of toxic potency (Van Gestel et al. 2001). Martin-Gil et al. (2007) also studied the use of earthworm Eisenia fetida and vermicomposting in the treatment of high-molecular weight hydrocarbons asphaltenes from the prestige oil spill. Earthworms mineralized the asphaltenes, thus eliminating it from the system. Sinha et al. (2008) studied the remedial action of earthworms on PAHs contaminated soils obtained from a former gasworks site in Brisbane, Australia. Results showed that the earthworms could remove nearly $80 \%$ of the PAHs as compared to just 47 and $21 \%$ where it was not used and only microbial degradation occurred. Ameh et al. (2013) investigated the use of earthworms (Eudrilus eugeniae) for vermi-assisted bioremediation of petroleum hydrocarbon-contaminated mechanic workshop soils. After 35 days of treatment, earthworm inoculation affected a higher drop in total petroleum hydrocarbon contents as compared to the samples without worms, indicating that earthworms may be used as biocatalysts in the bioremediation process.

Hyperiodrilus africanus is a species of earthworms widely distributed in humid tropical Africa (Lavelle et al. 1999). Populations of this species are found throughout West (Ivory Coast, Nigeria) and Central Africa (Congo, Democratic Republic of Congo, Angola) both in natural and disturbed areas derived from humid savannas and forests (Madge 1969; Omodeo 1954; Tondoh and Lavelle 2005).

Although other species of earthworms have been used for bioremediation, literature on the bioremediation of crude oil with earthworms $H$. africanus is not available, hence this study seeks to determine the effectiveness of hydrocarbon degrading potentials of the earthworm $H$. africanus on crude oil-contaminated soil and to determine the fate of the contaminant taken by the earthworms, if they are bioaccumulated or biodegraded in the tissues of the earthworms.

\section{Materials and methods}

\section{Test substrate}

Top soil not exceeding a depth of five inches after clearing the vegetation cover was dug with a shovel and collected into a bucket besides the Botanical Garden, Faculty of Life 
Sciences, University of Benin. The collected soil was sundried by spreading it on a flat, clean board surface for $48 \mathrm{~h}$. The dried soil was sieved using a $5 \mathrm{~mm}$ mesh plastic filter according to ISO standard 11268-1 (ISO 1993) to remove debris and large stones.

\section{Test organisms}

The earthworms used for the experiment were collected around the main campus of the University of Benin immediately after rainfall while crawling around to seek shelter. All earthworms were held in a holding facility for days prior to the experiment for acclimatization purposes and were regularly checked on a daily basis to ascertain their health condition. Prior to the experiment, earthworms were identified by Stephen Owa, using methods described by Owa (1992). The crude oil used for the experiment was obtained from Chevron Escravos Terminal, Delta State, Nigeria.

\section{Experimental design}

Four rectangular containers with cover lid and clips on both sides of the edges measuring $20 \times 9 \times 12 \mathrm{~cm}$ were purchased from the market. The containers were weighed with a Digital Sensitive Weighing balance (Scoute SE410X0.019, Ohaus Computer, USA) and were properly labeled using tape and a permanent marker. $1 \mathrm{~kg}$ (ISO 1993) of the sun-dried soil was then weighed into each of the four containers using Camry Emperors scale manufactured by Dial Spring Scale, China. With the aid of a $10 \mathrm{ml}$ glass beaker, $5 \mathrm{ml}$ of crude oil was thoroughly mixed, into each of the four containers having $1 \mathrm{~kg}$ each of soil and were moistened with distilled water to the water holding capacity of the soil. The treatments with crude oilcontaminated soil were left to stay for 7 days in the laboratory exposed to the elements.

After 7 days, cow dung was freshly collected within the campus and about $50 \mathrm{~g}$ each of the cow dung weighed was thoroughly mixed into the containers with crude oil-contaminated soil.

Immediately after the addition of additives, earthworms were sorted out of the holding containers, washed with clean water and ten earthworms of the species $H$. africanus measured and weighed were inoculated into the crude oilcontaminated soil and the replicates except the control. A netting material cut into sizes was placed on top of each of the containers and the cover lid frame was placed on top of it to hold it firmly with the help of the clips on both sides of the containers. This is done to avoid escape of the earthworms and allow free flow of oxygen into the treatments. The setup was placed inside the laboratory and checked morning and evening on a daily basis.

\section{Laboratory analyses}

Prior to the contamination of the soil and after contamination, samples were collected with a spatula, placed in an aluminum foil, labeled and taken to a laboratory to determine the physicochemical parameters of the soil, total petroleum hydrocarbon (TPH) and the benzene, toluene, ethylbenzene and xylene (BTEX) constituents.

For every 30 days, samples of the contaminated soil from each of the treatments were collected for laboratory analyses. For each of the contaminated soils, the physicochemical parameters such as $\mathrm{pH}$, total organic carbon, sulfate, nitrate and phosphate, sodium, potassium, calcium, magnesium were determined using procedures by the AOAC (2005). The TPH was determined using Atomic Absorption Spectrophotometer (AAS) as described by Miroslav and Vladimir (1999) while BTEX constituents in the crude oil (Figs. 1, 2, 3 ,4) contaminated soil were determined using Gas Chromatography with Flame Ionization Detector (GC-FID) from Agilent Technologies Inc., United States. At the termination of the experiment, earthworms were analyzed to determine the TPH and BTEX in the tissues using GC-FID.

\section{Results}

\section{Death and survival of earthworms}

At the termination of the experiment, no death was recorded in the population of the earthworm species used for the study.

\section{Physicochemical parameters}

The physicochemical parameters showed a variation within 90 days of the experiment. There was a gradual increased

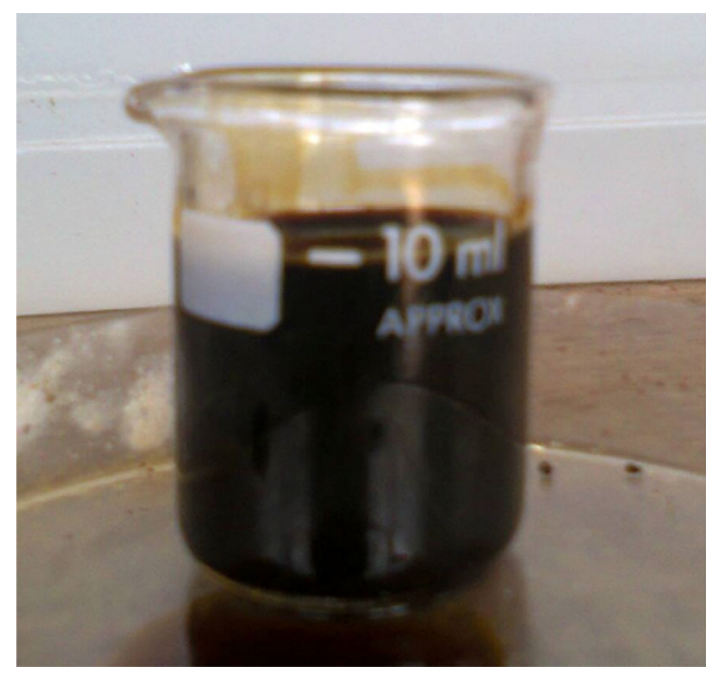

Fig. 1 Crude oil 
in the $\mathrm{pH}$ of the contaminated soil with inoculation of earthworm after 30, 60 and 90 days, $(0.93,2.78$ and $3.90 \%)$ respectively compared to the control where there is a decrease. There was a significant $(P<0.05)$ decrease in the crude oil-contaminated soil after inoculation of $H$. africanus within 30, 60 and 90 days in the total organic carbon $(3.47,9.25,56.64 \%)$, sulfate $(3.88,37.63$, $57.66 \%)$, nitrate $(3.86,37.63,57.69 \%)$, phosphate $(3.74$, $37.61,57.73 \%)$, sodium $(3.89,37.57,57.69 \%)$, potassium $(3.91,37.78,57.68 \%)$, calcium $(3.91,37.68,57.69 \%)$ and magnesium $(4.06,37.68,57.68 \%)$ compared to the control

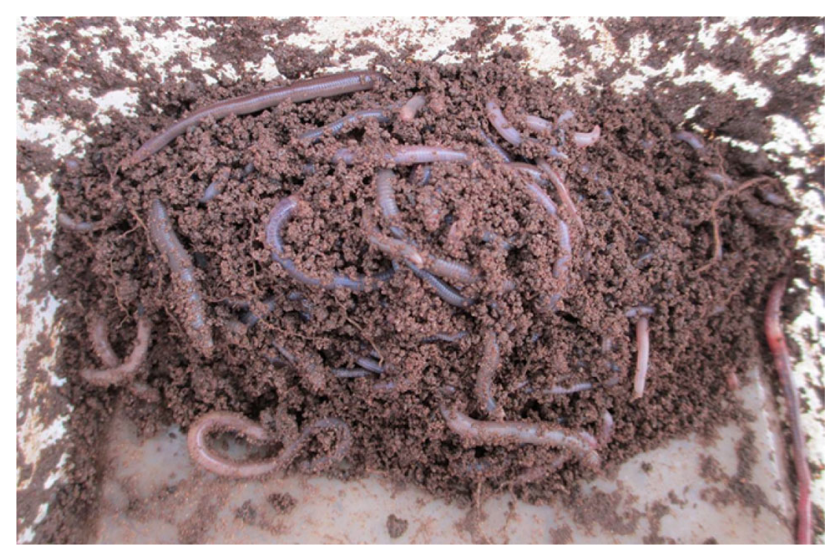

Fig. 2 Earthworm holding container

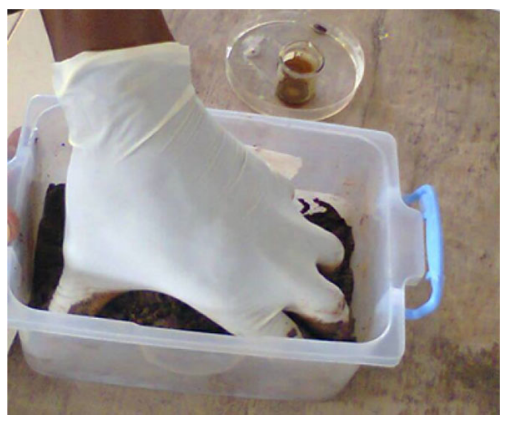

Fig. 3 Mixing crude oil into $1 \mathrm{~kg}$ of soil without earthworms with a $10.55 \%$ decrease after 90 days of the study (Fig. 5).

\section{Total petroleum hydrocarbon bioremediation}

Total petroleum hydrocarbon content in crude oil-contaminated soil with $H$. africanus decreased significantly $(P<0.05, F=16,503.64)$ after 30,60 and 90 days of the experiment by $22.01,44.29$ and $68.29 \%$, respectively, but in the control, it only decreased by $11.87 \%$ (Fig. 6).

\section{Benzene, toluene, ethylbenzene and xylene bioremediation}

Benzene, toluene, ethylbenzene and xylene decreased with inoculation of $H$. africanus into crude oil-contaminated soil (Fig. 7). Benzene decreased by 3.65, 50.60 and $84.73 \%$ $(F=181,785.77, P<0.05)$, toluene by $10.79,75.95$ and $100.00 \%(F=3242.62, P<0.05)$, ethylbenzene by 5.72 , 78.24 and $100.00 \%(F=5217.28, P<0.05)$ and xylene by $37.26,66.16$ and $100.00 \%(F=2484.56, P<0.05)$ after 30, 60 and 90 days of the study.

\section{Bioaccumulation/biodegradation of TPH and BTEX}

Analyses of the tissues of the earthworms, $H$. africanus at the end of the study showed that the earthworms bioaccumulated $58.05 \%$ TPH, $48.42 \%$ benzene, $31.86 \%$ toluene, $63.20 \%$ ethylbenzene and $18.14 \%$ xylene in crude oil-contaminated soil.

To calculate the percentage biodegraded, the formula below was adopted:

$\operatorname{Biod}_{\mathrm{C}}=I_{\mathrm{C}}-F_{\mathrm{C}}-T_{\mathrm{C}}$

where $\operatorname{Biod}_{C}$ is the concentration of pollutant biodegraded at the end of the experiment, $I_{\mathrm{C}}$ is the initial concentration of pollutant at the beginning of the experiment, $F_{\mathrm{C}}$ is the final concentration of pollutant at the end of the experiment, and $T_{\mathrm{C}}$ is the concentration in the tissues of the earthworms at the end of the experiment
Fig. 4 Experimental setupthree replicates and control

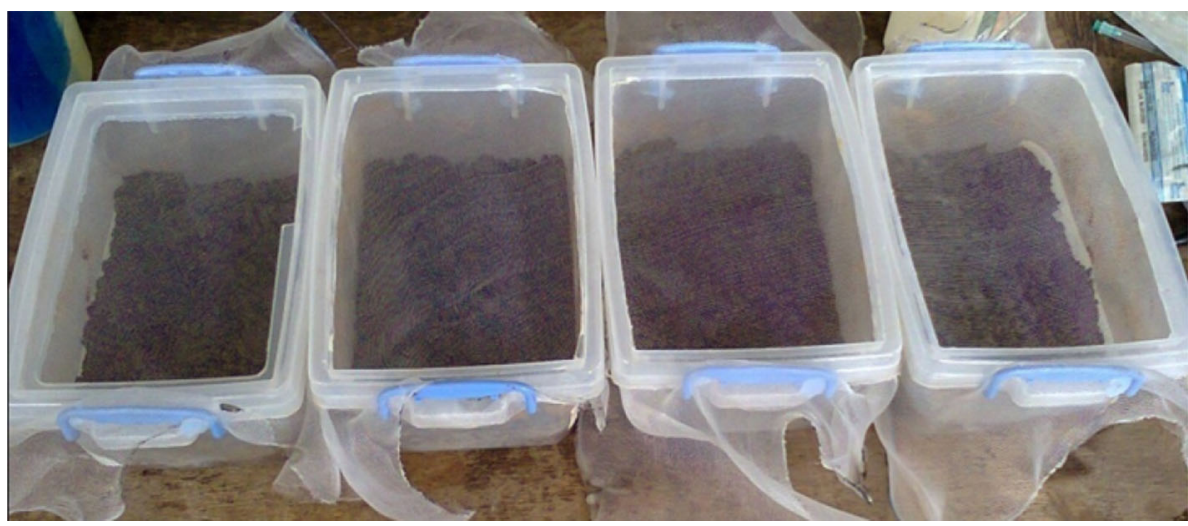




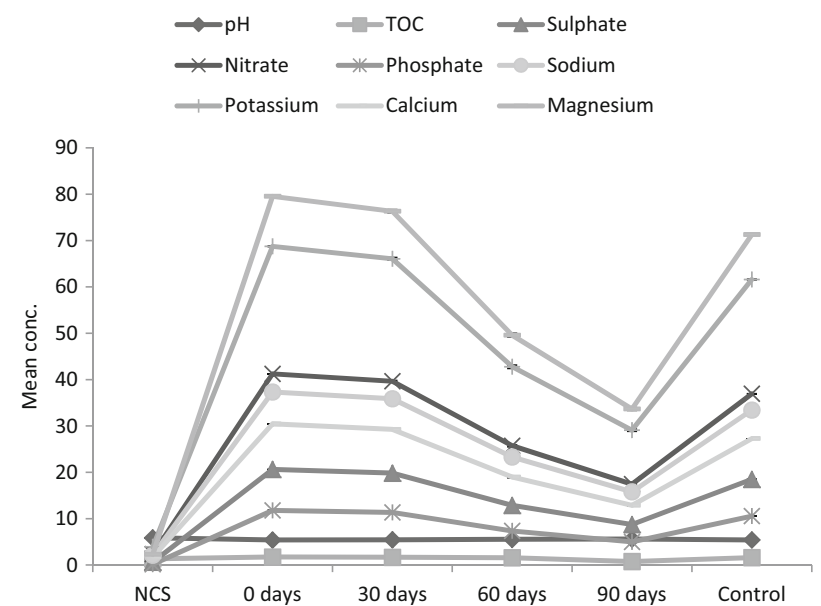

Fig. 5 Physicochemical parameters of crude oil-contaminated soil with earthworms

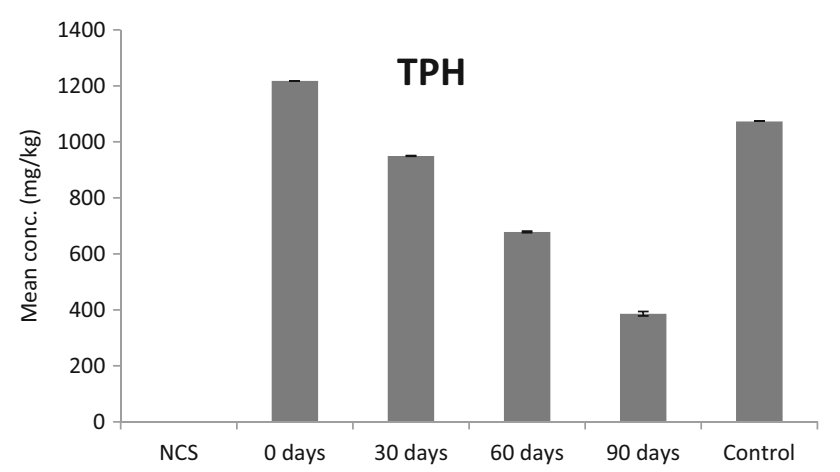

Fig. 6 TPH in crude oil-contaminated soil with H. africanus

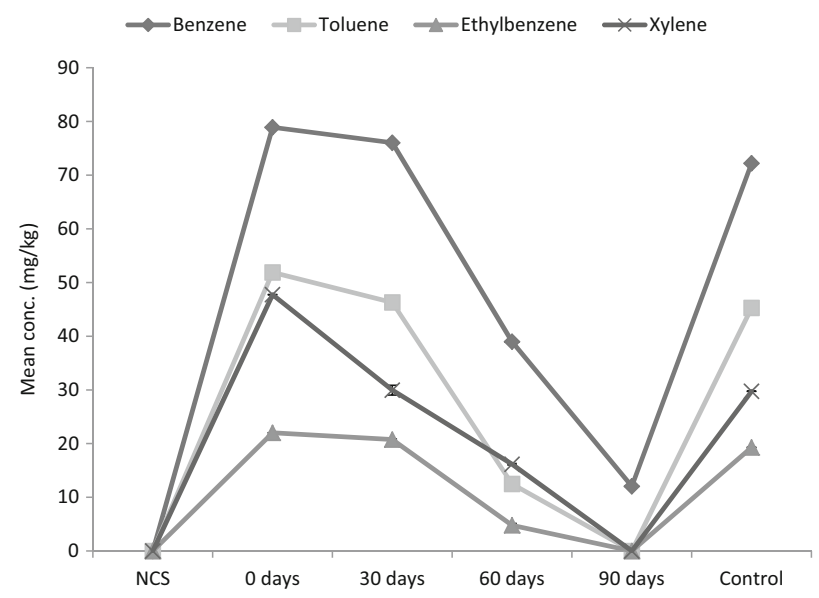

Fig. 7 Bioremediation of BTEX in contaminated soil with earthworms

The results revealed that the earthworms, $H$. africanus, biodegraded $10.24 \%$ TPH, $36.34 \%$ benzene, $68.14 \%$ toluene, $36.80 \%$ ethylbenzene and $81.86 \%$ xylene (Fig. 8).

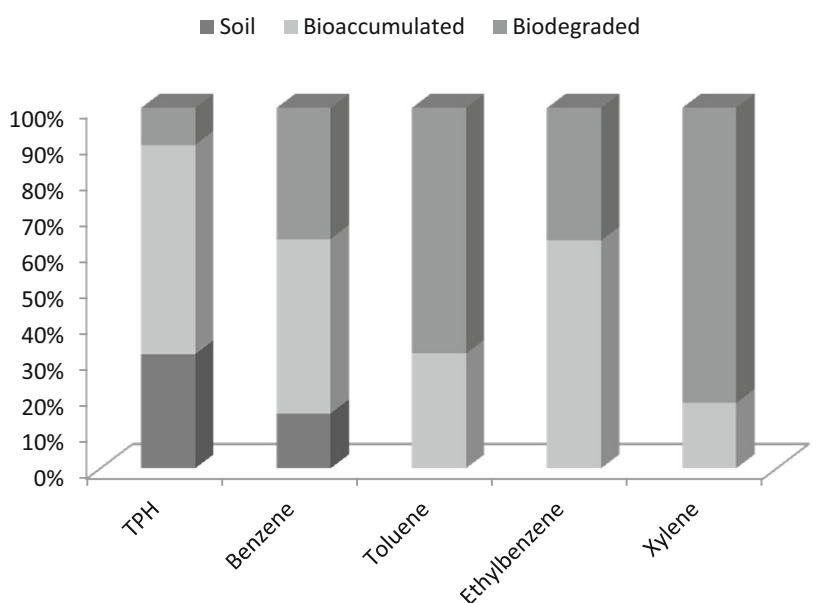

Fig. 8 Bioaccumulation/biodegradation of TPH and BTEX in earthworms

\section{Discussion}

Bioremediation has become a universally acceptable technology for the removal of a wide range of contaminants, especially generated from the petrochemical industries from the environment.

In this present study, all the earthworms survived the concentration $(5 \mathrm{ml})$ of crude oil contaminated into the $1 \mathrm{~kg}$ of soil and significantly degraded the TPH and BTEX hydrocarbons in the media.

Ameh et al. (2011) reported $100 \%$ survival of earthworms in $150 \mathrm{~g}$ of used engine oil. At the end of our study, earthworms re-introduced into non-polluted soil continue their normal activities. The idea that some workers have used more than $5 \mathrm{ml}$ of oil in other regions of the world where heavy and sour crude oil is available led to the first attempt to use $10 \mathrm{ml}$ for the experiment. This was the thinking based on the fact that the Nigerian crude oil is light and maybe less toxic, but such concentration resulted in the death of the earthworms in less than $48 \mathrm{~h}$. This agrees with the findings of Dorn and Salanitro (2000) which reported that light oil was the most toxic oil in their study. Heavy oils were least toxic showing LC50s of $100 \%$ or greater after $2 \pm 3$ months time in either soil. The light oil in the soils was significantly more toxic than medium and heavy oils (Dorn and Salanitro 2000).

Earthworms commonly found in agricultural fields thrive at neutral $\mathrm{pH}$, but can tolerate a $\mathrm{pH}$ from 5.0 to 8.0, (Duiker and Stehouwer 2008). The $\mathrm{pH}$ of the soil decreased from 5.85 to 5.39 after contamination and gradually increased from 5.39 to 5.60 after inoculation of earthworms. It is a favoured opinion that the activities of earthworms in soil tend to bring the $\mathrm{pH}$ towards neutrality. The increase in $\mathrm{pH}$ is probably due to the $\mathrm{pH}$ buffering action of organic molecules produced in the gut of earthworms (Duiker and 
Stehouwer 2008) in the bioremediation process. It is possible that since the $\mathrm{pH}$ is still within the tolerable range (Edwards and Aracon 2006) for the survival and normal functioning of the earthworms, it is not a neutral approach at the end of the study. Sandor and Schrader (2012) observed that as a general trend, the recorded $\mathrm{pH}$ values were higher at the end of the experiments compared to the initial start value. Azarpira et al. (2013) reported that the $\mathrm{pH}$ value at final stage was increased for all the treatments as compared to initial stage for the vermicomposting process with E. eugeniae.

There was a significant decrease $(P<0.05)$ in total organic carbon, sulfate, nitrate, phosphate, sodium, potassium, calcium and magnesium with a decrease towards restoring the normal conditions of the soil to the background levels prior to contamination of soil. Ceccanti et al. (2006) on the combination of earthworms and compost for the ecological remediation of hydrocarbon polluted soil in Finland reported that the chemical parameters showed a decrease in the concentration of total carbon, total phosphorus, and the available carbon and nitrogen in all the treatments. This suggests a progressive degradation of organic compounds, probably including the pollutants $(\mathrm{Cec}-$ canti et al. 2006). Although at the end of our study, only phosphate was restored back to the initial background levels of soil.

TOC slightly increased after crude oil contamination of soil and decreased (1.73-0.75) after inoculation with $H$. africanus below the background levels at the end of the experiment. The reason for the further decrease is not clear, but it is probable that the earthworms needed some degree of TOC in the biodegradation process of breaking down pollutant in the crude oil-contaminated soil. Edwards and Arancon (2006) stated that breakdown of compost materials results in low C:N ratios. Sandor and Schrader (2012) reported a significant decrease in soil organic carbon at the end of their experiment. Azarpira et al. (2013) reported that as compared to initial stage, organic carbon decreased in the final stage. The combined action of earthworms and gut microorganisms may be responsible for the loss of organic carbon in the form of carbon dioxide (Prakash and Karmegam 2010). Azizi et al. (2013) also recorded reduction in organic carbon during vermicomposting of sludge. They explained that loss in organic carbon was due to the use of organic carbon by earthworms and microorganisms as source of energy. Similar trend was also reported by Kennette et al. (2002) with Lumbricus terrestris, Ceccanti et al. (2006) with E. fetida and Ameh et al. (2011) with $L$. terrestris, while Singer et al. (2001), Schaefer et al. (2005), Iordache and Borza (2012) and Ameh et al. (2013) reported higher values.

Sulfate, nitrate, phosphate, sodium, potassium, calcium and magnesium in soil increase significantly after crude oil contamination and decrease significantly after inoculation of earthworms. These soil nutrients are required in the right proportions for the proper functioning of soil fertility for agricultural purposes. At the end of the experiment, these parameters were higher than the initial background levels prior to the experiment. The increase above the background levels is an indication that the earthworm was able to stabilize the soil from a moderately fertile soil to a fertile soil needed for soil flora and fuana. Sinha et al. (2009) reported that the earthworm increases these minerals in the soil by enhancing the soil quality and nutrients. Similar trend was reported by Zavala-Cruz et al. (2013) on crude oil-contaminated soil with earthworms in Mexico. Manyuchi et al. (2013) reported an increase in soil potassium content after 25 days period, but in contrast Sandor and Schrader (2012) reported a significantly lower amount of nitrates compared to those in the corresponding control treatments at the end of their experiment while Iordache and Borza (2011) stated that the concentrations of nitrates and nitrites decreased with 6.93 and $21.43 \%$, respectively, which are attributed to earthworms, because they consume large amounts of nitrogen in their digestion.

TPH was not detected in the soil prior to contamination. At the end of the study, the TPH in the contaminated soil with earthworms decreased significantly by $68.29 \%$ but for the control without earthworm it only decreased by $11.87 \%$. There is yet no clear understanding of the biochemical pathway for the bioaccumulation or breakdown of organic compounds in earthworms, but it may not be unconnected with the interactions of chemicals such as enzymes secreted by the earthworms and the decomposer microbial flora associated with the gut of earthworms (Sinha et al. 2010). Schaefer et al. (2005) reported that the TPH concentration decreased significantly in samples with L. terrestris, E. fetida within 28 days. Schaefer and Filser (2007) also conducted an experiment on the influence of earthworms (E. fetida, Allolobophora chlorotica, and L. terrestris) and organic additives on the biodegradation of oil-contaminated soil (9500 $\mathrm{mg} \mathrm{TPH} / \mathrm{kg}$ soil dry wt.) in Germany. GC analyses showed that the concentration of TPH was significantly reduced in soils with earthworms compared to the treatments without worms. The efficiency of oil degradation depended on earthworm species. They suggested that earthworms could be applied in the later stages of the bioremediation of even highly contaminated sites, when TPH concentrations and potential toxicity have been decreased to a tolerable or moderate level. Earthworms might be especially useful in in situ remediation by the so-called natural attenuation where the soil is not disturbed by heavy machinery (Schaefer and Filser 2007). Other workers that reported decrease in TPH or crude oil include Schaefer (2001), Ceccanti et al. (2006), Tomoko et al. (2005), Getliff et al. (2002), while Callaham et al. (2002) reported no effect. 
Benzene, toluene, ethylbenzene and xylene (BTEX) were below detection limits in the uncontaminated soil. After contamination, the values in the BTEX constituents were in the following descending order; Benzene $>$ Toluene $>$ Xylene $>$ Ethylbenzene in the contaminated soil. The BTEX constituent decreases accordingly after inoculation of earthworms after 30 and 60 days. Only benzene was detected in the soil at the end of the study, while toluene, ethylbenzene and xylene were below detection limit. Hutchins et al. (1992) and Junfeng et al. (2008) also reported a significant reduction in BTEX in petrochemical-contaminated soils. Hutchins et al. (1992) reported average benzene breakthrough of $74.3 \pm 5.8 \%$, $75.9 \pm 12.1 \%$, and $63.1 \pm 9.6 \%$ in the columns with limited oxygen, limited oxygen plus nitrate, and nitrate alone, respectively. Junfeng et al. (2008) suggested that all the BTEX substrates could be anaerobically biodegraded to non-detectable levels within 70 days when the initial concentrations were below $100 \mathrm{mg} / \mathrm{kg}$ in soil. Toluene was degraded faster than any other BTEX compounds, and the high-to-low order of degradation rates were toluene $>$ ethylbenzene $>m$-xylene $>o$-xylene $>$ benzene $>p$-xylene (Junfeng et al. 2008). Contreras-Ramos et al. (2006) reported PAH removal of $51 \%$ for anthracene, $47 \%$ for benzo(a)pyrene and $100 \%$ for phenanthrene in soil with the earthworm E. fetida. Krishna et al. (2011) also reported $100 \%$ bioremediation of phenols after $96 \mathrm{~h}$ with the earthworms E. fetida, E. eugeniae and Anantapur sp. for phenol concentration of 20,40,60,80 and $100 \mathrm{ppm}$. Tharakan et al (2004) investigated the biotransformation of polychlorinated biphenyls (PCB's) in sludge and sediment from the Ralston Street Lagoon (RSL) SUPERFUND site in Gary, Indiana, United States with E. fetida. Vermicomposting bioreactors (VBs) were established with mass fractions of contaminated sludge ranging from 10 to $75 \%$. All sludge concentrations demonstrated around an $80 \%$ reduction in total PCB concentration by the time of termination of the experiment. Singer et al. (2001) achieved $55 \%$ removal of the total soil PCB with Pheretima hawayana as compared to only $39 \%$ in identically treated soils without earthworms. Earthworm-treated soils achieved upwards of $65 \%$ PCB degradation at subsurface depths, as compared to $44 \%$ in soils without earthworms.

In bioremediation studies with macrofauna, it is essential to point out the transport and fate of the contaminant. This will give a clear understanding of the bioremediation pathway and the need to take extra steps towards effective removal of the contaminant from the food chain. Although a significant amount of TPH and BTEX were lost from the soil and biodegraded by the earthworm, at the end of the experiment about $57.35 \%$ of TPH and $29.61 \%$ of BTEX were bioaccumulated inside the tissues of the earthworms while $15.01 \%$ TPH and $8.35 \%$ benzene were still remaining in the soil.
Tharakan et al. (2004) reported that the bulk of the removal of PCBs from the sludge appeared to be transported into the earthworm biomass. Approximately, $20 \%$ of the PCBs remained in the sludge-earthworm bedding mixture at the time of termination of each of the experimental studies. As suggested by Tharakan et al. (2004), it is entirely possible that a certain percentage of contaminants are hard to access and hence recalcitrant to any transformative activity. In soil where contamination has taken place for years, the aging phenomenon suggested by several workers can be responsible for the hindering or recalcitrant effects of the contaminant, but in laboratory-contaminated soil or lands where pollution occurs within few months, this aging phenomenon is very unlikely. Another possibility is that the earthworms did not have sufficient time and sufficient additional feeding, hence it may be that with sufficient additional resources and longer experiments, more complete biotransformation may occur.

The ability for this species of earthworms to biodegrade contaminant is not known but it is clear from our study that biodegradation and bioaccumulation are processes that are simultaneously taking place in the earthworms. It is also possible that earthworms can tolerate some concentration of contaminant without affecting its regular biological function and it only breakdown contaminant when it is exceeding its tolerance threshold. There is need for further research to shed light on this. In earthworms-contaminated soil, grasses started growing in the media after 20 days while in the control grasses appeared after 41 days.

\section{Conclusion}

Developing an effective strategy for the removal of petrochemicals from contaminated environment is one of the major challenges facing developing countries including Nigeria in her quest for economic development. This research has shown that the earthworm $H$. africanus has the potentials to bioaccumulate and biodegrade hydrocarbons from crude oil-polluted soil. The addition of additives or nutrients for the earthworms will increase and enhance the bioremediation process. These findings suggest that the earthworm could be applied in the later stages of bioremediation, even in highly contaminated soil with crude oil when the toxicity of the contaminant may have decreased or pre-treated to a tolerable level. Earthworm bioremediation does not only remove the contaminant but also enrich the soil by the addition of vermicast after reworking of the contaminated soil in the gut of the earthworm.

Acknowledgments The authors thank Prof. (Mrs) Beatrice Iloba for helping with inputs in designing the initial research, Prof. Stephen Owa for identifying the earthworms, Prof. Rotimi for his advice and Christina Macci for shedding light on their application on similar research in Italy. 
Conflict of interest The authors have declared that no conflict of interest exists.

Open Access This article is distributed under the terms of the Creative Commons Attribution 4.0 International License (http:// creativecommons.org/licenses/by/4.0/), which permits unrestricted use, distribution, and reproduction in any medium, provided you give appropriate credit to the original author(s) and the source, provide a link to the Creative Commons license, and indicate if changes were made.

\section{References}

Ameh AO, Mohammed-Dabo IA, Ibrahim S, Ameh JB, Azienge CD, Tanimu Y (2011) Earthworm survival in used engine oil contaminated soil spiked with manure. Int J Biol Chem Sci 5(3):923-929

Ameh AO, Mohammed-Dabo IA, Ibrahim S, Ameh JB (2013) Earthworm-assisted bioremediation of petroleum hydrocarbon contaminated soil from mechanic workshop. Afr J Environ Sci Technol 7(6):531-539. doi:10.5897/AJEST2013.1506

AOAC (2005) Methods of analysis. Association of Official Analytical Chemists, Washington

Azarpira H, Behdarvand P, Dhumal K (2013) Effect of different bulking materials and earthworms species on bioremediation potential of municipal sewage sludge. J Environ Earth Sci 3(12):68-72

Azizi AB, Lime MPM, Noor ZM, Abdullah N (2013) Vermiremoval of heavy metal in sewage sludge by utilising Lumbricus rubellus. Ecotoxicol Environ Safety 90:13-20. doi:10.1016/j.ecoenv.2012. 12.006

Callaham MA, Stewart AJ, Alarcon C, McMillen SJ (2002) Effects of earthworm (Eisenia fetida) and wheat (Triticum aestivum) straw additions on selected properties of petroleum contaminated soils. Environ Toxicol Chem 21:1658-1663

Ceccanti B, Masciandaro G, Garcia C, Macci C, Doni S (2006) Soil bioremediation: combination of earthworms and compost for the ecological remediation of a hydrocarbon polluted soil. Water Air Soil Pollut 177:383-397

Contreras-Ramos SM, Alvarez-Bernal D, Dendooven L (2006) Eisenia fetida increased removal of polycyclic aromatic hydrocarbons (PAHs) from soil. Environ Pollut 141:396-401

Dorn PB, Salanitro JP (2000) Temporal ecological assessment of soil contaminated soils before and after bioremediation. Chemosphere 40:419-426

Duiker S, Stehouwer R (2008) Penn State Agricultural Extension Service. Pennsylvania State University 2008

Edwards CA, Arancon NQ (2006) The science of vermiculture: the use of earthworms in organic waste management. In: Guerrero RD III, Guerrero-del Castillo MRA (eds) Vermi-technologies for Developing Countries, Proceedings of the International Symposium-Workshop on Vermi-technologies for Developing Countries, Philippine Fisheries Association, Inc., Los Baños, 16-18 Nov 2005, p 1-30

EPA (2000) Ethylbenzene United States, Environmental Protection Agency. http://www.epa.gov/ttnatw01/hlthef/ethylben.html. Accessed 10 Nov 2014

EPA (2012) Toluene United States, Environmental Protection Agency. http://www.epa.gov/ttnatw01/hlthef/toluene.html. Accessed 10 Nov 2014

Getliff J, McEwan G, Ross S, Richards R, Norman M (2002) Drilling fluid design and the use of vermiculture for the remediation of drill cuttings, AADE Technology Conference Drilling Fluids and Waste Management
Huff J (2007) Benzene-induced cancers: abridged history and occupational health impact. Int $\mathrm{J}$ Occup Environ Health 13(2):213-221. doi:10.1179/oeh.2007.13.2.213

Hutchins SR, Moolenaarb SW, Rhodesb DE (1992) Column studies on BTEX biodegradation under microaerophilic and denitrifying conditions. J Hazard Mat 32(2-3):195-214

IARC (2012) IARC Monographs on the evaluation of carcinogenic risks to humans. Volume 100F: a review of human carcinogens: chemical agents and related occupations. International Agency for Research on Cancer. http://monographs.iarc.fr/ENG/ Monographs/vol100F/mono100F-24.pdf. Accessed on 22 Oct 2014

Iordache M, Borza I (2011) Remediation of several chemical properties of soil through earthworm activity. Res J Agri Sci 43(4):101-105

Iordache M, Borza I (2012) The bioremediation potential of earthworms (Oligochaeta: Lumbricidae) in a soil polluted with heavy metals. J Food Agri Environ 10(2):1183-1186

ISO (1993) ISO 11268-1:1993: Soil quality-effects of pollutants on earthworms (Eisenia fetida)-Part 1: determination of acute toxicity using artificial soil substrate, International Organization for Standardization, ISO Central Secretariat, CP 56, CH-1211, Geneva 20, Switzerland

Junfeng DOU, Xiang LIU, Zhifeng HU (2008) Anaerobic BTEX degradation in soil bioaugmented with mixed consortia under nitrate reducing conditions. J Environ Sci 20(5):585-592

Kasper D, Braunwald E, Hauser S (2004) Harrison's principles of internal medicine, 16th edn. McGraw-Hill Professional, p 2607. ISBN 0071402357

Kennette D, Hendershot W, Tomlin A, Sauvé S (2002) Uptake of trace metals by the earthworm Lumbricus terrestris L. in urban contaminated soils. Appl Soil Ecol 19:191-198

Krishna MV, Hrushikesh N, Sreehari K, Aravind KT, Vidyavathi N, Pallavi A (2011) Study on bioremediation of phenol by earthworm. Int J Environ Sci 1(6):1268-1273

Lavelle P, Brussard L, Hendrix PF (1999) Earthworm management in tropical agroecosystems. Oxford University Press, Oxford, p 300

Ma WC, Imerzeel BJ (1995) Earthworm and food interactions on bioaccumulation and disappearance in soil of polycyclic aromatic hydrocarbons: studies on phenathrene and fluoranthene. Ecotoxicol Environ Safety 32:226-232

Madge DS (1969) Field and laboratory studies on the activities of two species of tropical earthworms. Pedobiologia 9:188-214

Manyuchi MM, Chitambwe T, Phiri A, Muredzi P, Kanhukamwe Q (2013) Effect of vermicompost, vermiwash and application time on soil physicochemical properties. Int $\mathbf{J}$ Chem Environ Eng 4(4):216-220

Martin-Gil J, Navas-Gracia LM, Gomez-Sobrino E, Correa-Guimaraes A, Hernandez- Navarro S, Sanchez-Bascones M (2007) Composting and vermicomposting experiences in the treatments and bioconversion of asphaltenes from the Prestige oil spill. Biores Technol 99:1821-1829

Miroslav R, Vladimir NB (1999) Practical environmental analysis. Royal Society of Chemistry, UK

NDES (1997) Niger Delta Environmental Survey (NDES) (1997) Environmental and socio economic characteristics

NNPC (2013) 2013 Annual Statistical Bulletin, Corporate Planning and Strategy Division, Nigerian National Petroleum Corporation. www.nnpcgroup.com. Accessed 20 Oct 2014

Omodeo P (1954) Eudrilinae e octochaetina delle Costa d'Ovorio (Oligochaeta) Momorie del Museo Civico di Storia. Naturale di Verona 4:162-166

Owa SO (1992) Taxonomy and distribution of Nigerian earthworms of the family Eudrilidae and their use as possible indicators of soil properties. Dissertation, Obafemi Awolowo University, IleIfe, Nigeria 
Prakash M, Karmegam N (2010) Vermistabilization of pressmud using Perionyx ceylanensis mich. Bioresour Technol 10:84648468. doi:10.1016/j.biortech.2010.06.002

Rana SV, Verma Y (2005) Biochemical toxicity of benzene. J Environ Biol 26(2):157-168

Salanitro JP, Dorn PB, Huesemann MH, Moore KO, Rhodes IA, Jackson LMR, Vipond TE, Western MM, Wisniewski HL (1997) Crude oil hydrocarbon bioremediation and soil ecotoxicity assessment. Environ Sci Technol 31(6):1769-1776. doi:10. 1021/es960793i

Sandor M, Schrader S (2012) Interaction of earthworms and enchytraeids in organically amended soil. North-Western J Zoo $8(1): 46-56$

Satchell JE (1983) Earthworm ecology-from Darwin to Vermiculture. Chapman and Hall Ltd., Cambridge, pp 1-178

Schaefer M (2001) Earthworms in crude oil contaminated soils: toxicity tests and effects on crude oil degradation. J Contam Soil Sed Water 35:708

Schaefer M, Filser J (2007) The influence of earthworms and organic additives on the biodegradation of oil contaminated soil. Appl Soil Ecol 36:53-62

Schaefer M, Petersen SO, Filser J (2005) Effects of Lumbricus terrestris, Allolobophora chlorotica and Eisenia fetida on microbial community dynamics in oil-contaminated soil. Soil Biol Biochem 37:2065-2076

Singer AC, Jury W, Leupromchai E, Yahng CS, Crowley DE (2001) Contribution of earthworms to PCB bioremediation. Soil Biol Biochem 33:765-775

Sinha RK, Bharambe G, David R (2008) Converting wasteland into wonderland by earthworms: a low-cost nature's technology for soil remediation: a case study of vermiremediation of PAH contaminated soil. Environ UK 28:466-475

Sinha RK, Sunil H, Gokul B, Swapnil P, Bapat PD, Kunal C, Dalsukh V (2009) Vermiculture biotechnology: the emerging costeffective and sustainable technology of the twenty first century for multiple uses from waste and land management to safe and sustained food production. Environ R J, NOVA Science Publishers, USA, Invited Paper, vol $3(2 / 3)$

Sinha RK, Herat S, Valani D (2010) Earthworms-the environmental engineers: review of vermiculture technologies for environmental management and resource development. In: Sinha RK, Herat $\mathrm{S}$ and Agarwal S (eds). Special Issue on 'Vermiculture Technology for Environmental Management and Resource Development. Int J Global Environ Issues, Inderscience Pub. USA 10:265-292. Nos. 3/4

Smith MT (2010) Advances in understanding benzene health effects and susceptibility. Ann Rev Pub Health 31:133-148. doi:10. 1146/annurev.publhealth.012809.103646

Tharakan J, Addagada A, Tomlinson DS (2004) Vermicomposting for the bioremediation of PCB congeners in SUPERFUND site media. Earth Worm Digest, December 4, 2005. www. wormdigest.org/content/186/2/. Accessed 10 Oct 2014

Tomoko Y, Toyota K, Shiraishi H (2005) Enhanced bioremediation of oil-contaminated soil by a combination of the earthworm (Eisenia fetida) and tea extraction residue. Edaphologia 77:1-9

Tondoh JE, Lavelle P (2005) Population dynamics of Hyperiodrilus africanus (Oligochaeta, Eudrilidae) in Ivory Coast. J Trop Ecol 21:493-500

UNEP (2011) Environmental Assessment of Ogoniland. United Nations Environment Programme. p 257. United Nations Environment Programme P.O. Box 30552 Nairobi, Kenya. www.unep.org/nigeria. Accessed 12 Oct 2014

Van Gestel K, Mergaert J, Swings J, Coosemans J, Ryckebore J (2001) Bioremediation of diesel oil-contaminated soil by composting with biowaste. Environ Pollut 125(5):361-368

Zavala-Cruz J, Trujillo-Capistran F, Ortiz-Ceballos GC, OrtizCeballos AI (2013) Tropical endogeic earthworm population in a pollution gradient with weathered crude oil. Res J Environ Sci 7:15-26. doi:10.3923/rjes.2013.15.26 